\title{
Soil physical quality after the fifth and sixth harvest of sugarcane in Brazilian Cerrado
}

\author{
José Luiz Rodrigues Torres ${ }^{1 *}$, Venâncio Rodrigues e Silva ${ }^{2}$, Renato Lara de Assis ${ }^{3}$, Zigomar Menezes \\ de Souza $^{4}$, Dinamar Márcia da Silva Vieira ${ }^{5}$ and Amanda Yamada Tamburús ${ }^{2}$ \\ ${ }^{1}$ Federal Institute of Mining Triangle (IFTM) - Uberaba, MG, Brazil \\ ${ }^{2}$ IFTM Uberaba, MG, Brazil, Scientific Initiation scholar of PIBIC/CNPq, PET/MEC, Brazil \\ ${ }^{3}$ Federal Institute of Goiano, Iporá, GO, Brazil \\ ${ }^{4}$ State University of Campinas, Faculty of Agriculture Engineering, Campinas, São Paulo, Brazil \\ ${ }^{5}$ Environmental Management, IFTM Uberaba, MG, Brazil
}

*Corresponding author: jlrtorres@iftm.edu.br

\begin{abstract}
On most cultivated areas with sugarcane the crop cycle allows between five to seven ratoon crops. The longevity of the plantation is determined by physical changes in soil during this period. This study evaluated the changes to soil physical properties after the fifth and sixth harvest of sugarcane using physical quality indicators. The experimental design was completely randomized blocks with two treatments, each with four replications: treatment 1 - sugarcane after the fifth ratoon crop; treatment 2 - sugarcane after the sixth ratoon crop. The physical attributes of soil: soil penetration resistance (PR), soil density (Sd) volumetric water content (VWC), macroporosity (Ma), microporosity (Mi) and total porosity (TP) were evaluated at six depths; while stability of aggregates (AS), mean weight diameter (MWD) and geometric mean diameter (GMD) were evaluated at four depths. Degradation of soil physical properties after the fifth and sixth ratoon crop was detected in this study. The area had a compacted layer between 0.10 and $0.30 \mathrm{~m}$ of depth. The correlations between soil density and the other parameters prove their importance as indicators of soil quality, and the need to evaluate soil moisture prior to tillage or harvest of the crop.
\end{abstract}

Keywords: Soil conservation, penetration resistance, soil density, macroporosity, microporosity, aggregate stability.

Abbreviations: SOM_Soil Organic Matter; SC_Soil Conservation; PR_Penetration Resistance; Sd_Soil Density; Ma_Macroporosity; Mi_Microporosity; TP_Total Porosity; AS_Aggregate Stability; VWC_Volumetric water content; MWD_Mean Weight Diameter; GMD_Geometric mean diameter; EA_Stability of aggregates; ASI_Aggregate Stability Index; AGRI_Diameter greater than $2.0 \mathrm{~mm}$; Si_Sensitivity index.

\section{Introduction}

Current tillage techniques of sugarcane are based on plowing during soil preparation and planting, which add traffic of machines and vehicles, causing changes both to physicochemical attributes and levels of soil organic matter (SOM). Some physical attributes have been frequently used to measure changes in soil quality to evaluate the impacts of tillage systems. Compaction, soil density, macroporosity, microporosity, total porosity, water holding capacity and aggregate stability are the most frequent ones (Torres et al., 2015). However, compaction has been identified as the primary cause of soil degradation because it negatively influences all other physical attributes (Materechera et al., 2009; Gorucu et al., 2006). This phenomenon creates a less favorable environment for the development of the root system of sugarcane (Otto et al., 2011; Kingwell et al., 2011). In sugarcane it is mainly caused during the harvest, either manual or mechanical (Oliveira Filho et al., 2015). Harvesters and transporters with total weight of 20-30 tones are used during this process. Their traffic, under varying humidity conditions, is repeated during the crop cycles, which vary between six to seven harvests. It causes soil structural degradation at different depths restricting root growth (Souza et al., 2012). The cane root system develops at greater depths then in other crops. The system consists of rhizomes and fasciculated roots, $85 \%$ of which are in the 0.0 $0.50 \mathrm{~m}$ layer, and $60 \%$ in the $0.20-0.30 \mathrm{~m}$ layer. (Oliveira Filho et al., 2015). Souza et al. (2014) emphasize that the physical changes in soil structure caused by compaction occur mainly in the top $0.0-0.40 \mathrm{~m}$ layer. Without chemical or physical obstructions these roots can reach depths greater than $2.00 \mathrm{~m}$. According to Alameda et al. (2012) the plant responds to soil compaction with changes in the development and operation of the roots. Those changes can affect productivity and product quality. Souza et al. (2014) observed that soil scarification allows a better development of the roots, helping the plant remain stable during dry periods. Evaluating areas with two cropping systems of sugarcane after the second and the third harvest, Campos et al. (2015) observed that those areas did not need soil ripping. The compaction level of the cane interrow still did not restrict the growth of the roots. However, Paulino et al. (2004) point out that the same did not happen after the fifth and the sixth harvest where scarification was required to reduce soil density and mechanical resistance for root penetration and increased soil permeability. 
Given this context, this study evaluated the changes in physical attributes of soil after the fifth and sixth harvest of sugarcane using physical quality indicators.

\section{Results and Discussion}

\section{The indicators of soil compaction}

Penetration resistance $(P R)$, soil density $(S d)$ and volumetric water content (VWC)

Analyzing the values of $\mathrm{PR}$ and $\mathrm{Sd}$, a compacted layer at depths from 0.10 to $0.30 \mathrm{~m}$ was observed (Table 1) The values were higher $(\mathrm{p} \leq 0.05)$ at depths between 0.10 and $0.20 \mathrm{~m}$ after the fifth harvest (4.32 MPa and $1.73 \mathrm{~kg} \mathrm{dm}^{-3}$ ), and the sixth harvest $\left(5.78 \mathrm{MPa}\right.$ and $1.75 \mathrm{~kg} \mathrm{dm}^{-3}$ ). They were followed by values at depths between 0.20 and $0.30 \mathrm{~m}$ after the fifth (3.63 MPa and $\left.1.69 \mathrm{~kg} \mathrm{dm}^{-3}\right)$ and the sixth (4.56 $\mathrm{MPa}$ and $1.70 \mathrm{~kg} \mathrm{dm}^{-3}$ ) harvest (Table 1), while VWC was constant throughout the profile. In general, soil penetration resistance values around $2.5 \mathrm{MPa}$ are considered low, while values around 3.5 to $6.5 \mathrm{MPa}$ are considered harmful for root development of legumes and grasses (Torres and Saraiva, 1999).

Table 1. shows PR limiting values in the layers of 0.10 0.20 and $0.20-0.30 \mathrm{~m}$, after the fifth and the sixth harvest, which may possibly have caused decreased productivity of sugarcane.

Regarding Sd, Reinert et al. (2001) propose the following critical values for a compacted soil as $1.55 \mathrm{~kg} \mathrm{dm}^{-3}$ and 200 $550 \mathrm{~g} \mathrm{~kg}^{-1}$ of clay. We observed that all evaluated layers reached critical values, with the highest intensity and greatest limitation to the growth of roots in the layers $0.10-0.20$ and $0.20-0.30 \mathrm{~m}$ after both harvests.

Evaluating soil management in sugarcane, Oliveira Filho et al. (2015) observed no differences in soil water content between plots and between layers up to $0.40 \mathrm{~m}$ of depth. PR values were not influenced by this variable, effectively indicating the compacted soil layers. Their data can be used without correcting them for humidity. Their results corroborate the results of our study. In practice, the knowledge of the relationship between PR and the water content is very important for a proper soil management because it helps to specify the conditions which impair or reduce root growth of plants.

\section{Macroporosity (Ma), microporosity (Mi) and total porosity} (TP)

In general, it was noted that Ma values decreased in the top layers, and increased in deeper layers, because the lowest values after the $5^{\text {th }}(4.63 \%)$ and the $6^{\text {th }}(4.33 \%)$ harvest were observed at the depth of $0.0-0.10 \mathrm{~m}$ and the highest values $(8.03 \%$ and $7.44 \%)$ at the depth of $0.50-0.60 \mathrm{~m}$. Regarding Mi and TP, an opposite pattern was observed i.e. the values increased in the surface layers and decreased in deeper layers after both harvests (Table 2). Ma and Mi values tended to have smaller variations at depths up to $0.40 \mathrm{~m}$, once there are no differences $(\mathrm{p} \leq 0.05)$ between variables and evaluated harvests. Analyzing the values in Table 2, degradation of Ma, $\mathrm{Mi}$ and PT was observed in the surface layer after both harvests, because values are significantly $(\mathrm{p} \leq 0.05)$ lower for $\mathrm{Ma}$ and higher for Mi and TP after both harvests, and tend to decrease after the $6^{\text {th }}$ harvest. Associating these changes with increased PR and Sd in the surface layer (Table 1), it can be assumed that there are restrictions to the development of the root system, such as reduced aeration which causes changes in water dynamics in soil rendering the soil more susceptible to erosion problems (Hickmann et al., 2012). The critical limit of Ma, which is considered as an impediment to the growth of roots, is $10 \%$ for annual crops. The ideal soil should contain $1 / 3$ of $\mathrm{Ma}(34 \%)$ and $2 / 3$ of $\mathrm{Mi}(66 \%)$, according to Kiehl (1979). It was observed that the pore size distribution mainly in the superficial layer (from 0.0 to 0.10 $\mathrm{m})$ was distant from the ideal, showing values of $12 \%$ and $88 \%$ of Ma after the $5^{\text {th }}$ harvest, and $8 \%$ and $92 \%$ of Mi after the $6^{\text {th }}$ harvest, respectively (Table 2 ). Pore distribution by size improved with increasing depths, however it did not reach the ideal arrangement. In a similar study, Souza et al. (2006) found that the traffic of agricultural machines and implements increased $\mathrm{PR}, \mathrm{Sd}$ and $\mathrm{Mi}$, and decreased $\mathrm{Ma}$ in the surface layer. The same study also pointed out that Mi means were significantly higher after the $6^{\text {th }}$ harvest, reaching $46.83 \%$ at the depth of $0.0-0.10 \mathrm{~m}$, versus $34.22 \%$ at the same depth after the previous harvest.

\section{Indicators of soil aggregation}

Mean weight diameter (MWD), Geometric mean diameter (GMD), Aggregate stability index (ASI) and Diameter greater than $2.0 \mathrm{~mm}$ (AGRI).

Regarding soil aggregation, we observed that the MWD, GMD, ASI and AGRI values were significantly higher at the depth of $0.0-0.10 \mathrm{~m}$ (Table 3) what proves the stability of the system in this layer. It can be explained by the presence of organic matter (thrash) on the surface after each harvest and the effect of the fasciculated root system on soil aggregates. Pereira et al (2010) point out that the higher values of MWD and GMD show the contribution of the soil management system to stabilize soil aggregates. All indicators (MWD, GMD, ASI and AGRI) were higher $(\mathrm{p} \leq 0.05)$ after the $6^{\text {th }}$ harvest, proving that the soil was protected against breakdown caused by the impact of rain drops and sudden moisture changes, while the deposition of organic matter on the soil surface accelerated microbial activity. Wendling et al. (2005), in a study evaluating five systems of soil management and analyzing the same traits of aggregation highlighted that microbial activity produces substances which help form and stabilize aggregates.

Analyzing the values of the AGRI index at the evaluated depths it can be noted that there was a better distribution of aggregates between sieve screens after the $6^{\text {th }}$ harvest, which can be explained by further development of the root system of the crop. Evaluating MWD, GMD, ASI and AGRI values in five soil management systems, Demarchi et al. (2011) observed that the best results occurred on the pasture with another grass (Urochloa brizantha), whose results (4.12 and $2.96 \mathrm{~mm}, 92.9 \%$ and $79.7 \%$ ) were significantly higher than the results (3.43 and $2.04 \mathrm{~mm}, 88.4$ and $63.7 \%$ ) of the native forest (control), respectively. The authors explained that this was due to higher soil aggregation promoted by the roots of plants grown in the area.

\section{Sensitivity index (Si)}

Regarding the sensitivity index ( $\mathrm{Si}$ ) applied to the MWD, when comparing the results after the $5^{\text {th }}$ and $6^{\text {th }}$ harvest, it 
Table 1. Values of soil penetration resistance, soil density and volumetric humidity of sugarcane interrows evaluated after the $5^{\text {th }}$ and $6^{\text {th }}$ harvest.

\begin{tabular}{|c|c|c|c|c|c|c|}
\hline \multirow[t]{2}{*}{ Layer } & PR & $\mathrm{Sd}$ & VHC & PR & $\mathrm{Sd}$ & $\mathrm{VHC}$ \\
\hline & \multicolumn{3}{|c|}{$5^{\text {th }}$ harvest } & \multicolumn{3}{|c|}{$6^{\text {th }}$ harvest } \\
\hline $\mathrm{m}$ & $\mathrm{MPa}$ & $\mathrm{kg} \mathrm{dm}^{-3}$ & $\mathrm{~cm}^{3} \mathrm{~cm}^{-3}$ & $\mathrm{MPa}$ & $\mathrm{kg} \mathrm{dm}^{-3}$ & $\mathrm{~cm}^{3} \mathrm{~cm}^{-3}$ \\
\hline $0.00-0.10$ & $2.87 \mathrm{Cb}$ & $1.67 \mathrm{Ba}$ & $0.22 \mathrm{Aa}$ & $3.83 \mathrm{Ca}$ & $1.68 \mathrm{Ba}$ & $0.21 \mathrm{Aa}$ \\
\hline $0.10-0.20$ & $4.32 \mathrm{Ab}$ & $1.73 \mathrm{Aa}$ & $0.21 \mathrm{Aa}$ & $5.78 \mathrm{Aa}$ & $1.75 \mathrm{Aa}$ & $0.20 \mathrm{Aa}$ \\
\hline $0.20-0.30$ & $3.63 \mathrm{Bb}$ & $1.69 \mathrm{Bb}$ & $0.23 \mathrm{Aa}$ & $4.56 \mathrm{Ba}$ & $1.70 \mathrm{Bb}$ & $0.21 \mathrm{Aa}$ \\
\hline $0.30-0.40$ & $2.63 \mathrm{Db}$ & $1.65 \mathrm{Cb}$ & $0.21 \mathrm{Aa}$ & $3.09 \mathrm{Da}$ & $1.66 \mathrm{Cb}$ & $0.21 \mathrm{Aa}$ \\
\hline $0.40-0.50$ & $1.97 \mathrm{Ea}$ & $1.60 \mathrm{Dc}$ & $0.23 \mathrm{Aa}$ & $2.25 \mathrm{Ea}$ & $1.62 \mathrm{Dc}$ & $0.23 \mathrm{Aa}$ \\
\hline $0.50-0.60$ & $1.69 \mathrm{Ea}$ & $1.60 \mathrm{Dc}$ & $0.23 \mathrm{Aa}$ & $1.78 \mathrm{Ea}$ & $1.61 \mathrm{Dc}$ & $0.23 \mathrm{Aa}$ \\
\hline $\mathrm{CV}(\%)$ & & 9.70 & & & 6.8 & \\
\hline
\end{tabular}

${ }^{\mathrm{ns}}=$ not significant; ${ }^{*}$ Significant $(\mathrm{p} \leq 0.05)$. Means followed by the same capital letters in the line compare the $5^{\text {th }}$ and $6^{\text {th }}$ harvest, and lower case letters in the column compare the depths, which do not differ by Scott-Knott test $(\mathrm{p} \leq 0.05)$. PR: Penetration Resistance; Sd: Soil Density; VWC: Volumetric water content.

Table 2. Values of macroporosity, microporosity and total porosity of sugarcane interrows after the $5^{\text {th }}$ and $6^{\text {th }}$ harvest.

\begin{tabular}{|c|c|c|c|c|c|c|}
\hline \multirow[t]{2}{*}{ Layer } & $\mathrm{Ma}$ & $\mathrm{Mi}$ & $\mathrm{TP}$ & $\mathrm{Ma}$ & $\mathrm{Mi}$ & TP \\
\hline & & $5^{\text {th }}$ harvest & & \multicolumn{3}{|c|}{$6^{\text {th }}$ harvest } \\
\hline $\mathrm{m}$ & \multicolumn{6}{|c|}{ 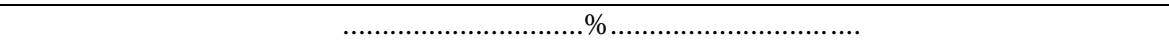 } \\
\hline $0.00-0.10$ & $4.63 \mathrm{Aa}$ & $34.22 \mathrm{Ab}$ & $38.85 \mathrm{Ab}$ & $4.33 \mathrm{Aa}$ & $46.83 \mathrm{Aa}$ & $51.16 \mathrm{Aa}$ \\
\hline $0.10-0.20$ & $6.48 \mathrm{Ba}$ & $31.00 \mathrm{Ab}$ & $37.49 \mathrm{Ab}$ & $6.01 \mathrm{Ba}$ & $37.37 \mathrm{Ba}$ & $43.38 \mathrm{Ba}$ \\
\hline $0.20-0.30$ & $7.62 \mathrm{Ca}$ & $32.30 \mathrm{Ab}$ & $39.92 \mathrm{Aa}$ & $6.86 \mathrm{Bb}$ & $37.58 \mathrm{Ba}$ & $44.44 \mathrm{Aa}$ \\
\hline $0.30-0.40$ & $8.33 \mathrm{Ca}$ & $32.50 \mathrm{Aa}$ & $40.83 \mathrm{Aa}$ & $6.36 \mathrm{Bb}$ & $35.42 \mathrm{Ba}$ & $41.78 \mathrm{Ba}$ \\
\hline $0.40-0.50$ & $8.03 \mathrm{Ca}$ & $32.34 \mathrm{Aa}$ & $40.37 \mathrm{Aa}$ & $7.44 \mathrm{Ca}$ & $35.11 \mathrm{Ba}$ & $42.54 \mathrm{Ba}$ \\
\hline $0.50-0.60$ & $8.03 \mathrm{Ca}$ & $31.14 \mathrm{Aa}$ & $40.15 \mathrm{Aa}$ & $7.44 \mathrm{Ca}$ & $35.00 \mathrm{Ba}$ & $41.35 \mathrm{Ba}$ \\
\hline CV (\%) & & 6.70 & & & 8.17 & \\
\hline
\end{tabular}

depths, which do not differ by Scott-Knott test $(\mathrm{p} \leq 0.05)$. Ma: Macroporosity; Mi: Microporosity; TP: Total Porosity.

Table 3. Values of mean weight diameter, geometric mean diameter, aggregate stability index, aggregate percentage index with a diameter greater than $2 \mathrm{~mm}$.

\begin{tabular}{|c|c|c|c|c|c|}
\hline Layer & MWD & GMD & ASI & AGRI & $\mathrm{Si}$ \\
\hline $\mathrm{m}$ & \multicolumn{2}{|c|}{...........mmm........... } & \multicolumn{3}{|c|}{...............\% \% } \\
\hline & \multicolumn{5}{|c|}{$5^{\text {th }}$ Harvest } \\
\hline $0.00-0.10$ & $2.18 \mathrm{aB}$ & $1.05 \mathrm{aB}$ & $57.37 \mathrm{aB}$ & $36.00 \mathrm{aB}$ & - \\
\hline $0.10-0.20$ & $0.95 \mathrm{bB}$ & $0.63 \mathrm{bB}$ & $60.88 \mathrm{aA}$ & $25.93 \mathrm{bB}$ & - \\
\hline $0.20-0.30$ & $0.98 \mathrm{bB}$ & $0.57 \mathrm{bB}$ & $33.89 \mathrm{bB}$ & $18.41 \mathrm{bB}$ & - \\
\hline $0.30-0.40$ & $1.07 \mathrm{bB}$ & $0.62 \mathrm{bB}$ & $47.42 \mathrm{aB}$ & $19.65 \mathrm{bB}$ & - \\
\hline \multicolumn{6}{|c|}{$6^{\text {th }}$ Harvest } \\
\hline $0.00-0.10$ & $4.33 \mathrm{aA}$ & $3.50 \mathrm{aA}$ & $83.02 \mathrm{aA}$ & $84.37 \mathrm{aA}$ & $1.99 \mathrm{~b}$ \\
\hline $0.10-0.20$ & $3.28 \mathrm{cA}$ & $2.03 \mathrm{cA}$ & $67.99 \mathrm{aA}$ & $59.47 \mathrm{cA}$ & $3.46 \mathrm{a}$ \\
\hline $0.20-0.30$ & $3.78 \mathrm{bA}$ & $2.65 \mathrm{bA}$ & $73.56 \mathrm{aA}$ & $71.39 \mathrm{bA}$ & $3.85 \mathrm{a}$ \\
\hline $0.30-0.40$ & $3.77 \mathrm{bA}$ & $2.42 \mathrm{bA}$ & $64.97 \mathrm{aA}$ & $71.64 \mathrm{bA}$ & $3.56 \mathrm{a}$ \\
\hline $\mathrm{CV}(\%)$ & 6.57 & 12.94 & 15.68 & 9.23 & 12.19 \\
\hline
\end{tabular}

* Significant $(\mathrm{p} \leq 0.05)$. Means followed by the same lowercase letters in columns compare depths after each harvest and capital letters in the columns compare values at the same depths between harvests (the $5^{\text {th }}$ and $6^{\text {th }}$ harvest), which do not differ by Scott-Knott test $(\mathrm{p} \leq 0.05)$. MWD: Mean Weight Diameter; GMD: Geometric mean diameter; ASI: Aggregate stability index; AGRI: Diameter greater than $2.0 \mathrm{~mm}$; Si: sensitivity index.

Table 4. Pearson's correlation coefficients between physical traits of soil in sugarcane after the $5^{\text {th }}$ and the $6^{\text {th }}$ harvest.

\begin{tabular}{|c|c|c|c|c|c|c|c|c|c|c|}
\hline \multirow[t]{2}{*}{ Varible } & \multicolumn{10}{|l|}{$5^{\text {th }}$ harvest } \\
\hline & PR & VWC & $\mathrm{Ma}$ & Mi & $\mathrm{TP}$ & MWD & GMD & ASI & AGRI & $\mathrm{Si}$ \\
\hline . & $0.99 *$ & $-0.58^{*}$ & $-0.48^{*}$ & $-0.03 *$ & $-0.71^{*}$ & $-0.37 *$ & $-0.27 *$ & $0.31 *$ & $-0.39^{*}$ & - \\
\hline PR & & $-0.51 *$ & $-0.39^{\mathrm{ns}}$ & $-0.10^{\mathrm{ns}}$ & $-0.73^{\text {ns }}$ & $-0.42^{\mathrm{ns}}$ & $-0.42^{\text {ns }}$ & $0.16^{*}$ & $-0.52 *$ & - \\
\hline $\mathrm{Ma}$ & & & & $-0.57^{\mathrm{ns}}$ & $0.70^{\mathrm{ns}}$ & $-0.84^{\mathrm{ns}}$ & $-0.89 *$ & $-0.63^{*}$ & $-0.82 *$ & - \\
\hline $\mathrm{Mi}$ & & & & & $0.13^{\mathrm{ns}}$ & $0.89^{\mathrm{ns}}$ & $0.83 *$ & $-0.01 * *$ & $0.91 * *$ & - \\
\hline $\mathrm{TP}$ & & & & & & $-0.12^{\mathrm{ns}}$ & $-0.24 *$ & $-0.71 *$ & $-0.09 *$ & - \\
\hline MWD & & & & & & & $0.99^{\mathrm{ns}}$ & $0.39 *$ & $0.99 *$ & - \\
\hline GMD & & & & & & & & $0.51 *$ & $0.98 *$ & - \\
\hline ASI & & & & & & & & & $0.34^{\mathrm{ns}}$ & - \\
\hline \multirow[t]{3}{*}{ AGRI } & & & & & & & & & & - \\
\hline & & & & & $6^{\text {th }}$ ha & & & & & \\
\hline & PR & VWC & $\mathrm{Ma}$ & Mi & $\mathrm{TP}$ & MWD & GMD & ASI & AGRI & $\mathrm{Si}$ \\
\hline $\mathrm{Sd}$ & $0.99 *$ & $-0.94 *$ & $-0.50 *$ & $0.32 *$ & $0.31 *$ & $-0.71^{*}$ & $-0.54 *$ & $-0.15^{*}$ & $-0.73^{*}$ & $0.24 *$ \\
\hline PR & & $-0.92^{*}$ & $-0.48^{\text {ns }}$ & $0.32 * *$ & $0.32^{\mathrm{ns}}$ & $-0.67^{\mathrm{ns}}$ & $-0.49^{\text {ns }}$ & $-0.08 *$ & $-0.69 *$ & $0.24^{\mathrm{ns}}$ \\
\hline VWC & & & $0.63^{*}$ & $-0.39^{*}$ & $-0.36^{*}$ & $0.79 *$ & $0.66^{*}$ & $0.37 *$ & $0.80 *$ & $-0.20 *$ \\
\hline $\mathrm{Ma}$ & & & & $-0.92 *$ & $-0.88 * *$ & $-0.65^{\mathrm{ns}}$ & $-0.74^{\mathrm{ns}}$ & $-0.75^{*}$ & $-0.64 *$ & $0.99^{\text {ns }}$ \\
\hline $\mathrm{TP}$ & & & & & & $0.79 *$ & $0.91 *$ & $0.98^{\mathrm{ns}}$ & $0.78^{\mathrm{ns}}$ & $-0.91 * *$ \\
\hline MWD & & & & & & & $0.97^{\mathrm{ns}}$ & $0.80 *$ & $0.99 *$ & $-0.75^{\mathrm{ns}}$ \\
\hline GMD & & & & & & & & $0.91 *$ & $0.97 *$ & $-0.82^{\mathrm{ns}}$ \\
\hline ASI & & & & & & & & & $0.78^{\text {ns }}$ & $-0.80 *$ \\
\hline AGRI & & & & & & & & & & $-0.74 *$ \\
\hline
\end{tabular}

PR: Penetration Resistance; VWC: Volumetric water content; Ma: macroporosity; Mi: microporosity; TP: total pore volume;: MWD: Mean Weight Diameter; GMD: Geometric mean diameter; ASI Aggregate stability index; AGRI: aggregates percentage index with a diameter greater than $2 \mathrm{~mm}$; Si: sensitivity index; Sd: Soil density; ${ }^{\mathrm{ns}}=$ not significant, $*$ and $* *=s i g n i f i c a n t$ at $\mathrm{p} \leq 0.01$ and $\mathrm{p} \leq$ 0.05 by Scott-Knott test, respectively. 
was observed that the variations are greater $(p \leq 0.05)$ in the subsurface layer $(0.10-0.40 \mathrm{~m})$ because this layer underwent soil restructuring due to a high input of organic matter, the activity of the root system and the lack of soil disturbance.

Evaluating two vegetation covers (sugarcane and pasture with Brachiaria), Fontana et al. (2010) observed that the Si values of soils under the pasture were higher than under sugarcane. They explained that lower $\mathrm{Si}$ values found in the sugarcane area reflected the damaging effect of conventional tillage system used in this culture. When analyzing the correlations between all the indicators, it was observed that the Sd and VWC were significantly, positively or negatively, correlated $(\mathrm{p} \leq 0.05)$ with all other indicators (Table 4).

\section{Correlations between the quality indicators}

The correlations show that the Sd was positively correlated with PR and ASI after the $5^{\text {th }}$ harvest and with PR, Mi, TP and $\mathrm{Si}$ after the $6^{\text {th }}$ harvest. The same correlation was found between VWC and Ma, Mi, TP, MWD, GMD, ASI, and AGRI after the $5^{\text {th }}$ and the $6^{\text {th }}$ harvest respectively, i.e., these variables increased simultaneously (Table 4 ). These results show the compaction caused by successive harvest system of sugarcane, which alter the physical structure of the soil, influencing virtually all other indicators.

However, there were negative correlations of $\mathrm{Sd}$ with VWC, Ma, Mi, TP, MWD, GMD, ASI, and AGRI. Also VWC was negatively correlated with ASI, Mi, TP and Si, after the $5^{\text {th }}$ and $6^{\text {th }}$ harvest, respectively, i.e. while these variables increased the others decreased. These correlations show that there is a decreasing soil aeration capacity in depth, influencing water infiltration, as evidenced by Hickmann et al. (2012) in a similar study with no-till system over a long period of time. Wendling et al. (2005), studying Latosols under different soil management systems, found positive correlations among MWD, GMD, AGRI and ASI indexes. The correlations among Sd and the other evaluated parameters prove their importance as indicators of soil quality because they are sensitive to changes caused by management, as highlighted by Torres et al. (2015). Beutler et al. (2004) found negative correlations of Sd with TP and $\mathrm{Ma}$ and positive correlations with Mi. The authors explained that this was due to the proximity of the particles caused by increasing mechanical pressure on the soil, which reduced the proportion of pores of larger diameter, and slightly increased the proportion of smaller ones.

The correlations between VWC and all other parameters show their importance at the time of tilling or harvest, since they directly influence PR and Sd, which affect root growth and crop yields.

\section{Materials and Methods}

\section{Site description}

The study was conducted in the commercial area of a sugar and alcohol plant in Uberaba, Minas Gerais, located at the geographical coordinates of $19^{\circ} 39^{\prime} 19^{\prime \prime} \mathrm{S}$ and $47^{\circ} 57^{\prime} 27^{\prime \prime} \mathrm{W}$ at an altitude of $795 \mathrm{~m}$. Sampling was carried out soon after harvest held in December 2013 ( $5^{\text {th }}$ harvest $)$ and December $2014\left(6^{\text {th }}\right.$ harvest).

\section{Soil type}

The soil was classified as Oxisol, with medium texture (Embrapa, 2013), in a wavy soft spot relief, presenting in the layer of $0.00-0.20 \mathrm{~m}: 210 \mathrm{~g} \mathrm{~kg}^{-1}$ of clay; $710 \mathrm{~g} \mathrm{~g}^{-1} \mathrm{~kg}$ of sand; $80 \mathrm{~g} \mathrm{~kg}^{-1}$ of silt; $\mathrm{pH}\left(\mathrm{CaCl}_{2}\right) 5.5 ; 76 \mathrm{mg} \mathrm{dm}^{-3}$ of P (Resin); 0.2 $\mathrm{cmol}_{\mathrm{c}} \mathrm{dm}^{-3}$ of $\mathrm{K} ; 2.2 \mathrm{cmol}_{\mathrm{c}} \mathrm{dm}^{-3}$ of Ca; $1 \mathrm{cmol}_{\mathrm{c}} \mathrm{dm}^{-3}$ of $\mathrm{Mg}$; $1.7 \mathrm{mmol}_{\mathrm{c}} \mathrm{dm}^{-3}$ of $\mathrm{H}+\mathrm{Al}$; and $3.27 \%$ of organic matter.

\section{Local climate}

The climate is classified as Aw, tropical and warm according to Köppen (1948), with cold and dry winters. The mean annual rainfall is $1600 \mathrm{~mm}$, temperature $22.6{ }^{\circ} \mathrm{C}$, and relative humidity 68\%. (Inmet, 2015).

\section{Experimental design and treatments}

The experimental design was completely randomized blocks with two treatments: 1 - sugarcane area after the fifth harvest; 2 - sugarcane area after the sixth harvest. The following physical traits: soil penetration resistance (PR), soil density (Sd) volumetric water content (VWC), macroporosity (Ma), microporosity (Mi) and total porosity (TP) were evaluated at six depths $(0.00-0.10 ; 0.10-0.20 ; 0.20-0.30,0.30-0.40,0.40$ 0.50 and $0.50-0.60 \mathrm{~m}$ ), while stability of aggregates (AS), mean weight diameter (MWD) and geometric mean diameter (GMD) were evaluated at four depths $(0.00-0.10 ; 0.10-0.20$; $0.20-0.30 ; 0.30-0.40 \mathrm{~m}$ ), with four replications each. Each plot consisted of 10 rows of sugarcane each 50 meters long $(15 \times 50 \mathrm{~m})$ and spaced $1.50 \mathrm{~m}$ apart, totaling $750 \mathrm{~m}^{2}$ per plot.

\section{Evaluated traits}

\section{Soil compaction indicators}

The PR of sugarcane interrows was determined at 12 points per plot, using impact penetrometer Model IAA / Planalsucar with conical tip angle of $30^{\circ}$. The results were obtained by counting the number of impacts. Then the data were converted to $\mathrm{kgf} \mathrm{cm}^{-2}$ using the equation $\mathrm{R}\left(\mathrm{kgf} \mathrm{cm}^{-2}\right)=5.6+$ $6.98 \mathrm{~N}$ (Sene et al. 1985). The results were multiplied by the constant 0.098 for processing in MPa units.

The soil density was determined using samples with undeformed structure and the volumetric ring method. The samples were collected into rings, $48 \mathrm{~mm}$ diameter and 53 $\mathrm{mm}$ height, with Uhland auger at the evaluated depths. The samples had been previously saturated for 24 hours. Consequently, the samples were evaluated in a suction unit at $0.60 \mathrm{~m}$ of water column, and finally they were dried at $105^{\circ} \mathrm{C}$ for 24 hours. The Ma was the difference between TP and Mi. Volumetric water content (VWC) was measured in the undisturbed samples using the volumetric ring method with the samples weighed, and placed in an oven at $105^{\circ} \mathrm{C}$ for 24 hours to determine the VWC.

\section{Indicators of the stability of soil aggregates}

Deformed samples were collected using a mattock from each plot at depths of $0.00-0.10 ; 0.10-0.20 ; 0.20-0.30 \mathrm{~m}$, to analyze aggregate stability (AS) following the method described by Kemper and Chepil (1965). We calculated the mean weight diameter (MWD) (Eq. 1) and the geometric mean diameter (GMD) (Eq. 2) using the aggregate mass values. The aggregate stability index (ASI) (Eq. 3) is a measure of the total soil aggregation and does not consider the aggregate distribution by classes, therefore, the greater the amount of aggregates $<0.25 \mathrm{~mm}$, the lower the ASI. The aggregate percentage index with a diameter greater than 2 $\mathrm{mm}$ (AGRI) represents the proportion of aggregates larger 
than $2 \mathrm{~mm}$, (Eq. 4). The soil aggregation indexes were calculated as follows:

MWD $=\sum$ (xi x wi $)$

Eq. 1

Where $x i$ is the mean diameter of classes $(\mathrm{mm})$; and wi is the proportion of each class relative to the total (Wendling et al., 2005).

$G A D=\exp \left\{\sum[(\ln [\mathrm{xi}] *[\mathrm{pi}])] / \sum[\mathrm{pi}]\right\} \quad$ Eq. 2

Where $\ln [\mathrm{xi}]$ is the natural logarithm of the mean diameter of classes, and PI is the weight $(\mathrm{g})$ retained in each sieve (Demarchi et al., 2011).

ASI $=\{($ S. w. - wp $<0,25) /($ (S. w. $)\} * 100 \quad$ Eq. 3

Where $S w$ is the sample weight, and wp $<0.25$ corresponds to the aggregates weight class $<0.25 \mathrm{~mm}$, given in $\mathrm{g}$ (Demarchi et al., 2011).

AGRI $=w i>2 \times 100$

Eq. 4

Where wi $>2$ is the aggregate proportion $>2 \mathrm{~mm}$ (Wendling et al., 2005).

To compare the MWD values after the $5^{\text {th }}$ and $6^{\text {th }}$ harvest we used the sensitivity index ( $\mathrm{Si}$ ) suggested by Bolinder et al. (1999) which estimates the intensity of changes of the desired attribute.

$\mathrm{Si}=\mathrm{as} / \mathrm{ac}$

Where: Si is the sensitivity index; "as" is the value of MWD after the fifth harvest; and "ac" is the value of the same variable obtained after the sixth harvest. The changes in the evaluated attributes are smaller when the $\mathrm{Si}$ value is closer to 1.

\section{Statistical analysis}

The results were analyzed for normality and homogeneity of data through Lilliefors, Cochran and Barttlet tests. The physical attributes and the evaluated indexes were submitted to the Pearson correlation analysis and analysis of variance using the SISVAR statistical program. The F test was applied to calculate the significance, and the means were compared by Scott-Knott test $(\mathrm{p} \leq 0.05)$.

\section{Conclusions}

The results of this study indicate that degradation of soil physical properties occurs after the fifth and the sixth harvest of sugarcane. The area featured a compacted layer between 0.10 and $0.30 \mathrm{~m}$ deep, caused by the harvesting system and infield transport of sugarcane. In addition to this, we found that positive and negative correlations between $\mathrm{Sd}$ and the other evaluated parameters are important as soil quality indicators. Finally, positive and negative correlations between water content and other attributes highlight the need to evaluate soil moisture prior to performing tillage or harvest of sugarcane.

\section{Acknowledgements}

The authors thank the Federal Institute of Mining Triangle (IFTM) - Uberaba, MG, Brazil, for the available infrastructure, Support Foundation to Research of Minas Gerais (Fapemig), and National Council for Scientific and Technological Development (CNPq) for funding the project and granting scholarship.

\section{References}

Alameda D, Anten NPR, Villar R (2012) Soil compaction effects on growth and root traits of tobacco depend on light, water regime and mechanical stress. Soil Till Res. 120:121129.
Beutler NA, Centurion JF, Roque CG (2004) Relação entre alguns atributos físicos e a produção de grãos de soja e arroz de sequeiro em Latossolos. Ci Rur. 34: 365-371.

Bolinder MA, Angers DA, Gregorich EG, Carter MR (1999) The response of soil quality indicators to conservation manage. Can Jour of Soil Sci. 79: 37-45.

Campos FS, Alves MC, Souza ZM, Torres JLR (2015) Cropping systems evaluation, fertilization, and effects on technological quality and sugarcane productivity. Afric Jour of Agric Res. 10: 3387-3393.

Demarchi JC, Perusi MC, Piroli EL (2011) Análise da estabilidade de agregados de solos da microbacia do Ribeirão São Domingos, Santa Cruz do Rio Pardo - SP, sob diferentes tipos de uso e ocupação. Rev Bras de Tec Apl Ci Agr. 4: 7-29.

Embrapa - Empresa Brasileira de Pesquisa Agropecuária (2013) Sistema brasileiro de classificação de solos. $3^{\mathrm{a}}$ ed. Brasília, DF; 2013, 353p.

Fontana A, Brito RJ, Pereira MG, Loss A (2010) Índices de agregação e a relação com as substâncias húmicas em Latossolos e Argissolo de tabuleiros costeiros, Campos dos Goytacazes, RJ. Rev Bras Ci Agr. 5: 291-297.

Gorucu S, Khalilian A, Han YJ, Dodd RB, Smith BR (2006) An algorithm to determine the optimum tillage depth from soil penetrometer data in coastal plain soils. Appl Eng in Agric. 22: 625-631.

Hickmann C, Costa LM, Schaefer, CEG, Fernandes RBA, Andrade CLT (2012) Atributos físico-hídricos e carbono orgânico de um Argissolo após 23 anos de diferentes manejos. Caatinga. 25: 128-136.

Inmet. 2015. The National Institute of Meteorology Ministry of Agriculture, Livestock and Supply. Available in <http://www.inmet.gov.br/portal>. Access on: 15/Apr/15.

Kemper WD, Chepil WS (1965) Size distribution of aggregation. In: Black C. A, editor. Methods of soil analysis. Am Soc of Agron. 499-510. (Agronomy Monoghaph, 9).

Kiehl EJ (1979) Manual de edafologia. São Paulo: Agronômica Ceres. 262p.

Kingwell R, Fuchsbichler A (2011). The whole-farm benefits of controlled traffic farming: An Australian appraisal. Agric Syst. 104:513-521.

Köppen W (1948) Climatologia: con un estudio de los climas de la tierra. México: fondo de cultura económica. 478 p.

Materechera SA (2009). Tillage and tractor traffic effects on soil compaction in horticultural fields used for peri-urban agriculture in a semi-arid environment of the North West Province, South Africa. Soil Till Res. 103:11-15.

Oliveira Filho FX, Miranda NO, Medeiros JF, Silva PCM, Mesquita FO, Costa TKG (2015) Zona de manejo para preparo do solo na cultura da cana-de-açúcar. Rev Bras de Eng Agr e Amb. 19: 186-193.

Otto R, Silva AP, Franco HCJ, Oliveira ECA, Trivelin PCO (2011) High soil penetration resistance reduces sugarcane root system development. Soil Till Res. 117:201-210.

Paulino AF, Medina CC, Azevedo MCB, Silveira KRP, Trevisan AA, Murata M (2004) Escarificação de um Latossolo Vermelho na pós-colheita de soqueira de canade-açúcar. Rev Br Ci Sol. 28: 911-917.

Pereira MG, Loss A, Beutler SJ, Torres JLR (2010) Carbono, matéria orgânica leve e $\mathrm{P}$ remanescente em diferentes sistemas de manejo do solo. Pesq Agr Bras. 45: 508-514. 
Reinert DJ, Reichert JM, Silva VR (2001) Propriedades físicas de solos em sistema de plantio direto irrigado. In: Carlesso R, Petry MT, Rosa GM, Ceretta CA (Ed.). Irrigação por aspersão no Rio Grande do Sul. Santa Maria: UFSM, 165p.

Sene M, Vepraskas MJ, Naderman GC, Denton HP (1985) Relationsships Of Soil Texture And Structure To Corn Yield Response To Subsoiling. Soc Soil Sci Soc of Am Jour. 49: 422-427.

Souza GS, Souza ZM, Silva RB, Barbosa RS, Araújo FS (2014) Effects of traffic control on the soil physical quality and the cultivation of sugarcane. Rev $\mathrm{Br} \mathrm{Ci}$ do Sol. 38: 135-146.

Souza HA, Marcelo AV, Centurion JF (2012) Carbono orgânico e agregação de um Latossolo Vermelho com colheita mecanizada de cana-de-açúcar. Rev Ci Agr. 43: 658-663.
Souza ZM, Marques Junior J, Cooper M, Pereira GT (2006) Micromorfologia do solo e sua relação com atributos físicos e hídricos. Pesq Agr Bras. 41: 487-492.

Torres E, Saraiva OF (1999) Camadas de impedimento do solo em sistemas agrícolas com a soja. Londrina: Empresa Brasileira de Pesquisa Agropecuária, 58p. (Circular Técnica, 23).

Torres JLR, Pereira MG, Assis RL, Souza ZM (2015) Atributos físicos de um Latossolo Vermelho cultivado com plantas de cobertura, em semeadura direta. Rev $\mathrm{Br}$ de $\mathrm{Ci}$ do Sol. 39: 428-437.

Wendling B, Jucksch I, Mendonça ES, Neves JCL (2005) Carbono orgânico e estabilidade de agregados de um Latossolo Vermelho sob diferentes manejos. Pesq Agr Bras. 40: 487-494. 